\title{
The Dynamics Between Dividends, Financing and Investments: Evidence From Jordanian Companies
}

\author{
Abdullah Al Daas ${ }^{1}$, Moid U. Ahmad ${ }^{2}$ \& Suleiman Jamal Mohammad ${ }^{3}$ \\ ${ }^{1}$ Business Department, Middle East University, Jordan \\ ${ }^{2}$ Scholeio (OPC) Private Limited, India \\ ${ }^{3}$ Accounting Department, Princess Sumaya University for Technology, Jordan \\ Correspondence: Dr. Suleiman Jamal Mohammad, Head of Accounting Department, Princess Sumaya University for \\ Technology, Jordan.
}

Received: March 16, 2020

Accepted: April 16, 2020

Online Published: July 7, 2020

doi:10.5430/ijfr.v11n4p231

URL: https://doi.org/10.5430/ijfr.v11n4p231

\begin{abstract}
Dividend decisions, Financing decisions and Investment decisions are three very imperative decisions taken by a firm. The effect of these decisions is on the performance of the firm which subsequently effects the valuation of the firm. These decisions in a firm are also influenced by the growth and status of the respective economy.

The current research attempts to analyze the dynamics between these three major decision areas and also assess their relationship with the market value of the firm. These dynamics are further tested against the economic growth of the respective economy. Annual data for 50 companies from Jordanian economy for the time period 2007-2018 is used to achieve the objective. Basic and advanced statistical techniques such as regression analysis and Vector Auto Regression (VAR) have been used in the study. The sample involved 50 Jordanian companies.

The study found that the value of the firm is affected by three key decisions (value drivers) of dividend, investment and financing and this effect is best measured at a lag of two years. Also the combined effect of the three value drivers is more than standalone effect.
\end{abstract}

Keywords: firm value, VAR, Jordan, dividend, investment, financing, corporate finance

\section{Introduction}

Management of a firm involves decision making at various levels and of various nature. Dividend decisions, Financing decisions and Investment decisions are three very imperative and critical decisions taken by a firm and also are the three important functions of a firm. The effect of these decisions is on the performance of the firm which subsequently effects the value of the firm. These decisions in a firm are also influenced and they influence the respective economy.

Research has found various types of value drivers for the company, financial (Debt equity ratio) or non-financial (number of employees). Kumar and Sujit (2018) study three value drivers involving financing, dividendand investment in a firm. Companies that can display a strong financial performance are by default more inclined to satisfy one of the most important stakeholders, namely investors and shareholders (Chakravarthy, 1986). Cho \& Pucik (2005) argued that financial performance as a method to satisfy investors can be represented by profitability, growth and market value.

Ali et al. (2015) analyzed the effect of dividend policy on stock prices and found very contrasting results that profit retention by firms will result in a decrease in the value of the stock market prices and that dividend payout has a positive impact on the share prices of respected stocks. Khaled et al. (2011) conducted a research on UK stock market and found a negative relation between dividend payout ratio and stock price changes. Abdullah et al. (2013) found that dividend theory holds in terms of the effect of dividend policy on market price.

Zafar et al. (2012) concluded that dividend payouts have high influence on shareholder's wealth and there is significant impact of dividend policy on the shareholder's wealth in banking companies in India. Yusof and Ismail (2016) conducted a study to investigate the determinants of the dividend policy of public listed companies in Malaysia and concluded that that the five factors that are earnings, debt, size, investment and largest shareholder 
have a significant influence on dividend policy. Ahmad and Murray (2019) studied the impact of information technology investment on output of the firm. The size of the firm is an important determinant for value creation in Gulf Cooperation Council firms (Kumar and Sujit, 2018). Leverage and Debt affects the value of the firm in a positive way (Cheng and Tzeng, 2014). Bhandari (1988) found that leverage and average returns are positively related with each other. Size as a proxy for market capitalization is an important determinant of average returns (Banz, 1981). Caby et al. (1996) confirm that the determinants of value creation are variables of profitability, financial policy, investment and dividend policy.

With an objective to understand the efficiency of firm management, it becomes imperative to study the value drivers in a firm from the perspective of investing, financing and dividend decisions (the three important functions of a firm) and their consequential effect on the value of the firm. Such a study is one of its kind in the context to Jordanian companies.

\section{Literature Review}

Researchers have studied financial ratios in the past to study the financial position and operations of a company. Modigliani \& Miller (1958) in their seminal paper highlight the insignificance of capital structure on the value of the firm. Fama and French (1996) found that dividends and debt convey information about profitability that hides any tax effects in a firm. Hang et al. (2017) found that capital structure mediates the relation between risk management and firm value and propose that managers should leave debt capacities unused but should instead use additional internal funds for investments. Dang et al. (2019) studied firm value and found that size and profitability of a firm positively affects enterprise value while capital structure affects it negatively. Abreu (2016) developed a theoretical model for the firm value based on parameters related to operational, investment, financial, dividends and tax. Monea (2009) studied the financial position of companies through profitability ratios. Similarly, Karacaer and Kapusuzoölu (2008) studied 30 ratios of different types for 61 companies at Istanbul Stock Exchange. Jianjun, et al (2008) focused on the significance of Return on Equity (ROE) in shareholder's equity. Pene (1983) and Degos et al. (1988) studied the linkage between strategic position of a firm and its financial performance. Dividend payments indicate about the higher cash flow generation potential of firms (Hakansson,1982). Bhandari (1988) found that the leverage and average returns of firms are positively related. Caby et al. (1996) suggest that the value of a firm can be affected with variables of profitability, financial policy, investment and dividend policy. Leverage has a negative effect on firm value and thus debt should be used judiciously, (Fosu et al, 2016). Martínez-Carrascal and Ferrando (2008), found that investment decisions are significantly constrained by firm's financial position. Ahmad and Murray (2019) studied the information Technology effects on profitability and sustainability of firms in India.

Various researches have highlighted the role of three key functional aspects of firm performance, financing, investing and dividends as inputs into the process and value of the firm as output but this dynamic was not found to be studied much in the context of gulf region and Jordan, specifically.

\section{Research Methodology}

The effect of dividends and financing on the value of the firm has been studied largely in literature but the combined effect of these two along with investment decisions has not been studied in literature and is a research gap for Jordanian economy. This study attempts to achieve this objective. The general research objective of the study is to bring new insights into the dynamics between value of the firm, dividend decisions, investment decisions and financing decisions, in general and specifically in context to Jordanian firms.

Ahmad (2015) integrated macroeconomics data with corporate data in India and used VAR based study. Khaled et al. (2011), Abdullah et al. (2013) and Zafar et al. (2012) used multiple regression analysis in a similar research. Ali et al. (2015) took 45 non-financial companies for 12 years as a sample. Zafar et al. (2012) did a similar study on five years' data for Indian banks. The current research uses dividend payout ratio (dividend decisions), amount of fixed assets (investment decisions) and debt equity ratio (financing decisions) as the independent variables and market price (value of the firm) as the dependent variable. The GDP levels of the Jordanian economy was also included in the analysis to understand the integration of these variables with the economy. The variables used in the study are Dividend payout ratio (DP), Debt-Equity ratio (DE), Fixed Assets (FA), Current Market Price (CMP) and Gross Development Product (GDP).

The data set initially used for analysis was the annual average of all 50 companies (Industry average) for 18 years (2000-2017) for the five study variables. The analysis has been done at two levels, one at industry and economy's level and another at company's level. SPSS 16.0 and Gretl software were used for data analysis. Basic and advanced statistical techniques such as regression analysis and Vector Auto Regression (VAR) have been used in the study. 
Durbin-Watson (DW) statistic has been used to interpret autocorrelation. The source of the data was the database from the Central Bank of Jordan.

Accordingly, four null hypotheses are prepared for analysis:

H01: The value of a firm is not dependent on dividend decisions

$\mathrm{H} 02$ : The value of a firm is not dependent on financing decisions

H03: The value of a firm is not dependent on investment decisions

H04: The GDP is not dependent on industry valuation

Table 1. List of 50 sample companies

\begin{tabular}{|c|c|}
\hline Sl.No. & Company \\
\hline 1 & The Industrial Commercial \& Agricultural \\
\hline 2 & Premier Business And Projects Co. Ltd \\
\hline 3 & Jordan Chemical Industries \\
\hline 4 & National Chlorine Industries \\
\hline 5 & Jordan Industrial Resources \\
\hline 6 & Comprehensive Multiple Project Company \\
\hline 7 & National Cable \& Wire Manufacturing \\
\hline 8 & Arab Electrical Industries \\
\hline 9 & The Jordan Pipes Manufacturing \\
\hline 10 & Jordan Wood Industries / Jwico \\
\hline 11 & Ready Mix Concrte And Construction Supplies \\
\hline 12 & Arabian Steel Pipes Manufacturing \\
\hline 13 & Jordan Poultry Processing \& Marketing \\
\hline 14 & Jordan Dairy \\
\hline 15 & General Investment \\
\hline 16 & Al-Qaria Food \& Vegetable Oil Industries Co. P.L.C \\
\hline 17 & Universal Modern Industries \\
\hline 18 & National Poultry \\
\hline 19 & The Arab International Food Factories \\
\hline 20 & Nutri Dar \\
\hline 21 & Jordan Vegetable Oil Industries \\
\hline 22 & General Mining Cpmpany Plc \\
\hline 23 & Arab Aluminium Industry /Aral \\
\hline 24 & National Steel Industry \\
\hline 25 & Jordan Phosphate Mines \\
\hline 26 & The Jordan Cement Factories \\
\hline 27 & The Arab Potash \\
\hline 28 & Jordan Steel \\
\hline 29 & National Aluminium Industrial \\
\hline 30 & International Silica Industrial \\
\hline 31 & Travertine Company Ltd \\
\hline 32 & Arab Company For Investment Projects \\
\hline 33 & Pearl- Sanitary Paper Converting \\
\hline 34 & Dar Al Dawa Development \& Investment \\
\hline 35 & Arab Center For Pharm.\& Chemicals \\
\hline
\end{tabular}




\begin{tabular}{ll}
\hline 36 & Middle East Pharma. \&Chmical Ind. \& Medical Appliances \\
\hline 37 & Al-Ekbal Printing And Packaging \\
\hline 38 & The Jordan Worsted Mills \\
\hline 39 & Akary For Industries And Real Estate Investments \\
\hline 40 & El-Zay Ready Wear Manufacturing \\
\hline 41 & Al-Eqbal Investment Company Ltd \\
\hline 42 & Union Tobacco \& Cigarette Industries \\
\hline 43 & Jordanian Duty Free Shops \\
\hline 45 & Jordan International Trading Center \\
\hline 46 & Jordan Trade Fac \\
\hline 47 & Specialized Trading \& Investment \\
\hline 48 & Specialized Jordanian Investment \\
\hline 49 & Al-Zarqa Educational \& Investment \\
\hline 50 & The Arab Internationl For Education \& Investment. \\
\hline
\end{tabular}

\section{Discussion and Data Analysis}

\subsection{Industry and Economy Level Analysis}

Analyzing basics statistics (Table 2) of the industry, highest fluctuations in data was found for debt equity ratio (208\%) and lowest for average market price (22\%) indicating that for the time period for the industry, the leverage policy of the industry was volatile while average market valuation was stable. The correlations (Table 3) amongst the variables are low in general, indicating low Multi-collinearity for multivariate regression. This should not be a concern for multivariate regressions as the combined effect of three variables (DP, DE, FA) is the focus of the study. The logarithm value of the GDP level for the country along with the logarithm of other four variables were compared on time axis (Chart 1) which indicates a similar pattern in the values for debt equity and dividend payout (high correlation of 0.87 ). This high correlation between DP and DE validates the cost theory that increase in Debt, reduces the cost and thus increases the efficiency of the firm.

The GDP of the Jordanian economy was negatively correlated with DP (-0.02) and highly positively with FA (0.85) of the industry indicating that if companies start paying dividends, it will bring down the GDP growth and that capital investments made by industry will bolster the GDP growth rate.

Table 2. Basic statistics

\begin{tabular}{lll}
\hline Variable & Mean & C.V. \\
\hline DP & 50.79 & 0.74 \\
\hline DE & 1.24 & 2.08 \\
\hline FA & $1.92458 \mathrm{e}+007$ & 0.30 \\
\hline CMP & 2.96 & 0.22 \\
\hline GDP & 16207.6 & 0.50 \\
\hline
\end{tabular}

Table 3. Correlations of the variables

\begin{tabular}{llllll}
\hline DP & DE & FA & CMP & GDP & \\
\hline 1 & 0.87 & 0.19 & -0.04 & -0.02 & DP \\
\hline & 1 & 0.39 & 0.08 & 0.21 & DE \\
\hline & 1 & 0.09 & 0.85 & FA \\
\hline & & 1 & 0.17 & CMP \\
\hline
\end{tabular}




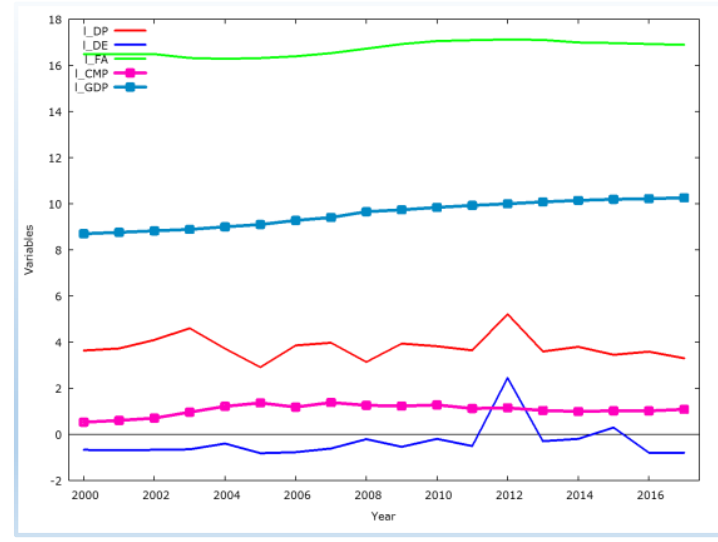

Figure 1. Graphical representation of log of time series for all five variables

The four null hypotheses are tested by applying univariate linear regression on industry data.

H01: The value of a firm is not dependent on dividend decisions

Low R-squared value (0.01) and high p-value (0.88) did not reject the null hypothesis H01.

H02: The value of a firm is not dependent on financing decisions

Low R-squared value (0.06) and high p-value (0.75) did not reject the null hypothesis H02.

H03: The value of a firm is not dependent on investment decisions

Low R-squared value (0.09) and high p-value (0.7) did not reject the null hypothesis H03.

\section{H04: The GDP is not dependent on industry valuation}

Low R-squared value (0.03) and high p-value (0.49) did not reject the null hypothesis H04.

All the four null hypothesis could not be rejected at absolute data and using univariate regression. Subsequently, the absolute data for the three variables were taken together as independent variables and regressed with market value as dependent variable and it was found that this multivariate regression is 'statistically insignificant' but can explain only $(5.2 \%)$ of variance in market value. Also, dividend payout and investments were found to be negatively related with market value.

Thus, the above regression analysis makes a case for further analysis using Vector Auto Regression (VAR) technique on lagged data (Sims, 1980).

The VAR system of absolute values at lag 2 was analyzed and selected based on Akaike Information Criteria (Akaike,1981) as the AIC score at lag 2 (44.47) was less that AIC score at lag1 (46.48). Also VAR system could not be run for more than two lags because of insufficient degrees of freedom. The individual coefficients are low and debt equity is negative with market value of the firm. The R-squared is $85 \%$ with adjusted R-squared at $67 \%$. The VAR system (Table 4) is significant with D-W statistic of 2.63. Null hypothesis of no ARCH effect holds and is not rejected for this VAR system. The residuals of VAR systems 1 indicated that they are stationary and thus made a good fit for forecasting. This VAR system can be said to be good model for market value prediction using the given independent variables.

Table 4. VAR system with market value (CMP) as dependent variable

\begin{tabular}{lll}
\hline Independent variable & Coefficient & p-value \\
\hline Constant & 0.71 & 0.32 \\
\hline CMP_1 & 0.12 & 0.64 \\
\hline CMP_2 & 0.67 & 0.03 \\
\hline DP_1 & 0.01 & 0.05 \\
\hline DP_2 & 0.007 & 0.19 \\
\hline
\end{tabular}




\begin{tabular}{lll}
\hline DE_1 & -0.15 & 0.064 \\
\hline DE_2 & -0.11 & 0.17 \\
\hline FA_1 & $-6.93096 \mathrm{e}-08$ & 0.23 \\
\hline FA_2 & $4.15 \mathrm{E}-08$ & 0.44 \\
\hline
\end{tabular}

Impulses of shocks were also analyzed for VAR system 1. The shock of DP on market price was observed as immediate in first year which comes down in second year and again goes up further in third year and keeps fluctuating. The shock is highly negative for DE in first year which remains negative for next few years. A similar negative shock was observed for FA also. This is also validated through negative beta coefficient for DE and FA (Table 4). This analysis is in confirmation with the VAR system coefficients and revalidates that individually the three independent variables have contrasting results but taken together, they explain a good amount of variance in market value.

The forecasting efficiency of VAR system is indicated graphically (Figure 2) and error statistics in table 5 which indicates that the model is good for forecasting.

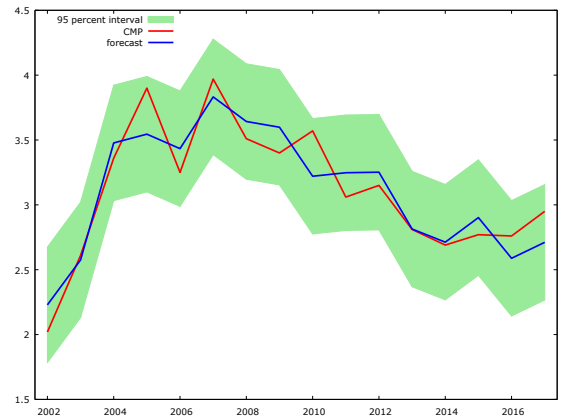

Figure 2. Graphical representation of the VAR model

Table 5. Forecast statistics of VAR system 1

\begin{tabular}{ll}
\hline Mean Error & $-2.7756 \mathrm{e}-017$ \\
\hline Mean Squared Error & 0.035 \\
\hline Root Mean Squared Error & 0.188 \\
\hline Mean Absolute Error & 0.161 \\
\hline Mean Percentage Error & -0.384 \\
\hline
\end{tabular}

Forecast Error Variance Decomposition (FEVD) was analyzed for VAR system and it was observed that the forecast error decomposition was maximum for debt equity ratio and it sustained its effect over 10 years. The effect of dividend payouts gradually increased over 10 years where as for fixed assets the effect increased marginally over 10 years.

\subsection{Company Level Analysis}

Subsequent to industry analysis, a company wise analysis was done for all 50 sample companies (Table 1). This analysis was done at company level where multivariate regression analysis was done on absolute data and on the lagged data (lag 2), respectively, for all the 50 companies. The dependent variable was market price (CMP) and the independent variables were dividend payout ratio (DP), debt equity ratio (DE) and fixed assets (FA). Data was used for 18 years (2000-2017) for each company respectively. The output from these two types of regression analysis for each company is indicated in table 6 .

Except for two companies (14 and 16) in Table 6, for all remaining 48 companies, the R-squared values (R2) of lagged regression was more that regression of absolute values indicating that a lag of two is best suited to forecast 
market value of a company using the given independent variables. This was validated by D-W statistics also at a lag of 2 years.

Table 6. Company wise regression results

\begin{tabular}{|c|c|c|c|c|c|c|}
\hline \multicolumn{4}{|c|}{ Absolute data regression } & \multicolumn{3}{|c|}{ Lagged regression } \\
\hline Company & $\mathrm{R} 2(\%)$ & Significance & DW & $\mathrm{R} 2(\%)$ & Significance & DW \\
\hline 1 & 35.65 & No & 1.03 & 90.81 & Yes & 2.48 \\
\hline 2 & 66.8 & Yes & 0.99 & 98.72 & Yes & 2.09 \\
\hline 3 & 70.31 & Yes & 1.64 & 83.77 & Yes & 2.47 \\
\hline 4 & 40.4 & No & 1.38 & 67.65 & No & 1.54 \\
\hline 5 & 29.65 & No & 2.02 & 65.70 & No & 2.22 \\
\hline 6 & 16.11 & No & 1.02 & 82.98 & Yes & 2.02 \\
\hline 7 & 53.3 & Yes & 1.1 & 79.66 & No & 1.8 \\
\hline 8 & 32.49 & No & 1.33 & 62.84 & No & 2.1 \\
\hline 9 & 14.28 & No & 0.9 & 59.55 & No & 2.14 \\
\hline 10 & 26.33 & No & 1.02 & 88.61 & Yes & 2.66 \\
\hline 11 & 24.59 & No & 0.58 & 82.32 & Yes & 2.71 \\
\hline 12 & 23.8 & No & 1.41 & 73.04 & No & 2.17 \\
\hline 13 & 30.18 & No & 0.97 & \multicolumn{3}{|c|}{ Data Insufficient } \\
\hline 14 & 41.12 & No & 2.28 & 28.00 & No & 2.14 \\
\hline 15 & 28.29 & No & 0.7 & 88.65 & Yes & 2.4 \\
\hline 16 & 60.23 & Yes & 1.66 & 44.42 & No & 1.96 \\
\hline 17 & 28.32 & No & 0.87 & 78.76 & No & 2.2 \\
\hline 18 & 44.28 & Yes & 1.7 & 74.14 & No & 2.67 \\
\hline 19 & 54.21 & Yes & 1.06 & 75.57 & No & 2.13 \\
\hline 20 & 51.66 & Yes & 1.98 & 56.18 & No & 2.84 \\
\hline 21 & 34.63 & No & 2.05 & 81.67 & Yes & 1.98 \\
\hline 22 & 24.23 & No & 0.31 & 84.89 & Yes & 1.69 \\
\hline 23 & 3.81 & No & 0.83 & 39.59 & No & 2.21 \\
\hline 24 & 55.1 & yes & 1.27 & 83.21 & Yes & 3.01 \\
\hline 25 & 52.22 & yes & 0.78 & 98.96 & Yes & 2.78 \\
\hline 26 & 40.15 & no & 0.67 & 86.65 & Yes & 2.75 \\
\hline 27 & 62.31 & yes & 0.87 & 85.05 & Yes & 2.09 \\
\hline 28 & 43.75 & yes & 0.57 & 76.82 & No & 2.29 \\
\hline 29 & 58.94 & yes & 1.1 & 89.72 & Yes & 2.23 \\
\hline 30 & 28 & no & 1.26 & 61.96 & No & 2.16 \\
\hline 31 & 34.23 & no & 0.85 & 81.92 & Yes & 2.15 \\
\hline 32 & 16.24 & no & 1.57 & \multicolumn{3}{|c|}{ Data Insufficient } \\
\hline 33 & 27.27 & no & 1.54 & 60.19 & No & 2.54 \\
\hline 34 & 55.12 & yes & 0.92 & 92.07 & Yes & 2.58 \\
\hline
\end{tabular}




\begin{tabular}{lllllll}
\hline 35 & 48.39 & yes & 0.68 & 81.74 & Yes & 2.66 \\
\hline 36 & 49.65 & yes & 1.31 & 79.25 & No & 2.45 \\
\hline 37 & 13.7 & NO & 0.66 & 71.09 & No & 2.14 \\
\hline 38 & 68.67 & Yes & 1.53 & 79.61 & No & 2.17 \\
\hline 39 & 3.47 & No & 0.84 & \multicolumn{4}{l}{ Data Insufficient } & \\
\hline 40 & 61.26 & Yes & 1.92 & \multicolumn{2}{l}{ Data Insufficient } & \\
\hline 41 & 41.13 & No & 0.71 & 96.23 & Yes & 2.69 \\
\hline 42 & 43.54 & Yes & 0.99 & 90.20 & Yes & 2.58 \\
\hline 43 & 85.36 & Yes & 1.62 & 91.85 & Yes & 2.22 \\
\hline 44 & 23.47 & No & 1.06 & 52.76 & No & 2.53 \\
\hline 45 & 8.09 & No & 0.63 & 86.36 & Yes & 2.89 \\
\hline 46 & 53.42 & Yes & 2.2 & 66.30 & No & 1.62 \\
\hline 47 & 83.35 & Yes & 2 & 96.75 & Yes & 2.56 \\
\hline 48 & 44.27 & Yes & 2.1 & 69.02 & No & 2.76 \\
\hline 49 & 46.97 & yes & 1 & 62.56 & No & 2.68 \\
\hline 50 & 31.74 & No & 1.53 & 77.72 & No & 1.63 \\
\hline
\end{tabular}

\section{Conclusion}

The general research objective of the study was to bring new insights in the dynamics between value of the firm, dividend decisions, investment decisions and financing decisions and in context to Jordanian companies. The research was successful in achieving the objectives. The industry analysis revealed that dividend decisions (DP), investment decisions (FA) and financing decisions (DE) are the three value drivers of the market value of the firm which consequently affects the economy. This effect is better explained when all three independent variables are taken together, rather than separately, as univariate regressions indicated low R-squared values. Also this combined effect is much better explained at a lag of 2 (R-squared value of $85 \%$ ) rather than absolute data (R-squared value of $5.2 \%$. The effect of financing decisions was found to be maximum (based on FEVD) on the value of the firm followed by dividend decisions and then investment decisions.

The market value of companies was found to be negatively related with dividend payout and capital investments of companies when multivariate regression was applied on absolute data of variables. This was a peculiar finding as dividend decisions and investment decisions are expected to have a contrary effect on value and on each other. This relationship can be extended in further research.

Financing decisions was found to be high and positively correlated with GDP also. The economy is more affected by the investment decisions of companies (correlation of 0.84) rather than financing and dividend decisions (negative correlation).

The combined effect of three key value drivers was revalidated in the company wise analysis also. The common conclusion was that the effect of these three value drivers is best fit at a lag of two years and that there is a combined effect of three key functional decisions on the value of the firm.

\subsection{Managerial Implications}

A firm should focus on the three functions (Investing, Financing and Dividend) to maximize its value in general and specifically on the three value drivers of the firm which are dividend payout ratios, debt equity ratio and the size of fixed assets. A VAR system based on these three value drivers could be a good model to estimate value of a firm. The economic policy makers should also keep a tab on the capital investments of the industry as it is positively correlated with the economic growth.

\section{References}

Abdullah Al- Hasan, M., Asaduzzaman, M., \& Al Karim, R. (2013). The Effect of Dividend Policy on Share Price: An Evaluative Study. IOSR Journal of Economics and Finance, 1(4), 06-11. 
https://doi.org/10.9790/5933-0140611

Abreu, R. (2016). From Accounting to Firm Value. Procedia Economics and Finance, 39, 685-692. https://doi.org/10.1016/S2212-5671(16)30290-8

Ahmad, M. U. (2015). An Analysis of market P/E using Auto Regression and Vector Auto Regression Models. Samvad: SIBM Pune Research Journal, 10, 116-120.

Ahmad, M. U., \& Murray, J. (2019). Understanding the connect between digitalization, sustainability and performance of an organization. International Journal of Business Excellence, 17(1), 83-96. https://doi.org/10.1504/IJBEX.2019.096909

Akaike, H. (1981). Likelihood of a Model and Information criteria. Journal of Econometrics, 16(1), 3-14. https://doi.org/10.1016/0304-4076(81)90071-3

Ali, A., Jan, F. A., \& Sharif, I. (2015). Effect of Dividend Policy on Stock Prices. Business \& Management Studies: An International Journal, 3(1), 56-87. https://doi.org/10.15295/bmij.v3i1.23

Al-Shawawreh, F. K. (2014). The Impact on Dividend policy on share price volatility: Empirical evidence from Jordanian stock market. European Journal of Business and Management, 6(38), 133-143.

Banz, R. W. (1981). The relationship between return and market value of common stocks. Journal of Financial Economics, 9, 3-18. https://doi.org/10.1016/0304-405X(81)90018-0

Bhandari, \& Laxmi, C. (1988). Debt/Equity ratio and expected common stock returns: Empirical evidence. Journal of Finance, 43, 507-528. https://doi.org/10.2307/2328473

Caby, J., Clerc, G., \& Koch, J. (1996). Strategic et finance: le processus de creation de vaieur. Revue Franpalse de Geslion, 108, 49-56.

Cheng, M.-C., \& Tzeng, Z. W.-C. (2014). Effect of Leverage on Firm Market Value and How Contextual Variables Influence this Relationship. Review of Pacific Basin Financial Markets \& Policies, 17(1), 1-63. https://doi.org/10.1142/S0219091514500040

Dang, H. N., Vu, V. T. T., Ngo, X. T., \& Hoang, H. T. V. (2019). Study the Impact of Growth, Firm Size, Capital Structure, and Profitability on Enterprise Value: Evidence of Enterprises in Vietnam. The Journal of Corporate Accounting and Finance, 30(1), 144-160. https://doi.org/10.1002/jcaf.22371

Degos, J. (1988). Evaluation des socieies el de lews litres. Vuibert.

Fama, E. F., \& French, K. R. (1996). Investment Decisions, Financing Decisions, and Firm Value. https://doi.org/10.2139/ssrn.1871

Fornell, C. G., \& Larcker, D. F. (1981). Evaluating structural equation models with unobservable variables and measurement error. Journal of Marketing Research, 18(1), 39-50. https://doi.org/10.1177/002224378101800104

Fosu, S., Danso, A., Ahmad, W., \& Coffie, W. (2016). Information asymmetry, leverage and firm value: Do crisis and growth matter?. International Review of Financial Analysis, 46, 140-150. https://doi.org/10.1016/j.irfa.2016.05.002

Hakansson, N. (1982). To pay or not to pay dividends?. Journal of Finance, 37, 415-428. https://doi.org/10.1111/j.1540-6261.1982.tb03564.x

Hang, M., Geyer-Klingeberg, J., Rathgeber, A., \& Stöckl, S. (2017). If, When, and How Financial Decisions Affect Firm Value: A Meta-Analysis. http://doi.org/10.2139/ssrn.3091590

Hussainey, K., Mgbame, C. O., \& Chijoke-Mgbame, A. M. (2011). Dividend policy and share price volatility: UK evidence. The Journal of Risk Finance, 12(1), 57-68. https://doi.org/10.1108/15265941111100076

Karacaer, S., \& Kapusuzoölu, A. (2008). An Analysis of the Effect of Financial Ratios on Financial Situation of Turkish Enterprises Resulting from their Annual Operations. International Research Journal of Finance and Economics, 19, 139-149.

Kumar, B. R., \& Sujit, K. S. (2018). Value Drivers of GCC Firms-An Empirical Study. Journal of Developing Areas, 52(3), 199-210. https://doi.org/10.1353/jda.2018.0046

Martínez-Carrascal, C., \& Ferrando, A. (2008). The Impact of Financial Position on Investment: An Analysis for Non-Financial Corporations in the Euro Area. Documentos de Trabajo, 0820, 6-40. https://doi.org/10.2139/ssrn.1273546 
Modigliani, F., \& Miller, M. (1958). The Cost of Capital, Corporation Finance, and the Theory of Investment. American Economic Review, 48(3), 261-297.

Monea, M. (2009). Financial Ratios- Reveal How a Business is Doing?. Annals of the University of Petroani Economics, 9(2), 137-144.

Niu, J. J., Yue, H., \& Jiang, G. H. (2008), Profitability Analysis of Chinese Listed Firms: 1992-2004. Frontiers of Business Research in China, 2(4), 497-517.

Pene, D. (1983). Modeles d'evaiuation des entreprises et modeles strategiques. Analyse Fmancierc, 54, 55-62.

Sims, C. A. (1980). Macroeconomics and reality. Econometrica, 48(1), 1-48.

Tariq, Z. S. M., Chaubey, D. S., \& Khalid, S. M. (2012). A study on Dividend policy and its impact on the shareholders wealth in selected banking companies in India. International Journal of Financial Management, 2(3), 79-94. Retrieved December 27, 2018, from wwwstatisticaldb.cbj.gov.jo/index?action=level2\&lang=ar\&cat_id=20

Yusniliyana, Y., \& Suhaiza, I. (2016). Determinants of dividend policy of public listed companies in Malaysia. Review of International Business and Strategy, 26(1), 88-99. https://doi.org/10.1108/RIBS-02-2014-0030 